\title{
PROSES ELIMINASI WASTE DENGAN METODE WASTE ASSESSMENT MODEL \& PROCESS ACTIVITY MAPPING PADA DISPENSING
}

\author{
Andi Turseno \\ Program Studi Teknik Industri, \\ Universitas Bhayangkara Jaya, \\ Jl. Raya Perjuangan, Bekasi Utara, Bekasi Jawa Barat \\ Email : andi.turseno@gmail.com
}

\begin{abstract}
A b s trak
Peningkatan produktivitas dapat dilakukan dengan menghilangkan pemborosan yang terjadi di setiap aliran proses. Dengan mengidentifikasi pemborosan, mengurangi pemborosan dan membuat perbaikan maka dapat meningkatkan produktivitas pada dispensing. Penelitian ini menggunakan metode Waste Assessment Model (WAM) dan dilanjutkan dengan metode Process Activity Maping (PAM) untuk mengidentifikasi masalah sekaligus jalan untuk memperbaiki proses di dispensing. Berdasarkan analisa dengan metode WAM maka diperoleh hasil bahwa pemborosan inventory menempati urutan pertama (19,23\%), diikuti oleh pemborosan karena defect $(18,16 \%)$ dan terakhir adalah overproduction $(16,58 \%)$. Metode selanjutnya yang digunakan adalah Process Activity Maping dimana aktivitas menunggu $(89,9 \%)$ adalah aktivitas terlama. Sementara aktivitas yang bernilai tambah sebesar 4,56\%, aktivitas yang tidak bernilai tambah tapi diperlukan sebesar 6,24\% dan aktivitas yang tidak bernilai tambah sebesar 89,2\%. Sehingga untuk memperbaiki proses yang ada di dispensing diperlukan tindakan sebagai berikut: relokasi aktivitas dispensing, perubahan lay out aktivitas dispensing dan mengurangi waktu preparasi dengan cara pengelolaan inventori dengan baik.
\end{abstract}

Kata Kunci : pemborosan, waste assessment model, process activity maping, dispensing, inventory.

\section{PENDAHULUAN}

Peningkatan produktivitas terjadi bila adanya perampingan operasi yang dapat mengidentifikasi lebih dini pemborosan dan masalah kualitas yang akan terjadi ke depannya. Dalam usaha peningkatan produktivitas, perusahaan harus mengetahui kegiatan yang dapat meningkatkan nilai tambah (value added) produk dan menghilangkan pemborosan yang oleh karena itu diperlukan suatu pendekatan lean. Lean manufacturing merupakan metode ideal untuk mengoptimalkan performansi dari sistem dan proses produksi karena mampu mengidentifikasi, mengukur, menganalisa dan mencari solusi perbaikan atau peningkatan performansi secara komprehensif.

Saat ini penggunaan konsep lean tidak hanya dapat diaplikasikan pada industri manufakturing tetapi sudah merambah ke bidang lain, seperti bidang jasa, rumah sakit dan pergudangan. Dalam hal konsep lean yang diterapkan pada bidang pergudangan, keberhasilan penerapan teknik lean dapat mereduksi lead time, order picking time, dan waktu utk handling material.

Ada banyak metode yang berhubungan dengan aplikasi dan pentingnya konsep eliminasi pemborosan di berbagai jenis industri yang berbeda. Metode analisa yang digunakan untuk mengidentifikasi pemborosan adalah dengan menggunakan metode waste assessment model. Kelebihan dari model ini adalah keserdehanaan dari matrix dan kuesioner yang mencakup banyak hal dan mampu memberikan kontribusi untuk mencapai hasil yang akurat dalam mengidentifikasi akar penyebab dari pemborosan. Sementara metode lain yang digunakan adalah dengan process activity mapping tools. Tool ini dipergunakan untuk mengidentifikasi lead time dan produktivitas baik aliran produk fisik maupun aliran informasi. Tujuan dari pemetaan ini adalah untuk membantu memahami aliran proses, mengidentifikasi pemborosan, mengidentifikasi apakah suatu 
proses dapat diatur kembali menjadi lebih efisien, mengidentifikasi perbaikan aliran penambahan nilai.

Rumusan yang menjadi fokus dalam pencarian, pengukuran dan perencanaan sampai dengan pengambilan keputusan dari peningkatan produktivitas di dispensing adalah "Bagaimana konsep eliminasi pemborosan dapat menaikkan produktivitas di dispensing dan faktor faktor pemborosan apa yang mempengaruhi proses peningkatan produktivitas di Dispensing.

\section{METODE PENELITIAN}

Tahapan-tahapan penelitian yang peneliti lakukan sehingga pelaksanaan penelitian berjalan secara sistematis adalah sebagai berikut:

Tahap 1 : identifikasi disertai perumusan masalah dan menentukan tujuan penelitian.

Tahap 2 : melakukan studi literatur mengenai teori teori yang dipakai dalam penelitian ini.

Tahap 3 :pengumpulan data yang diambil dari literatur ataupun jurnal bertujuan untuk mendapatkan data data teori.

Tahap 4 : mengidentifikasi aliran material \& informasi.

Tahap 5 : identifikasi \& pengukuran waste dengan cara metode waste assessment model.

Tahap 6 : identifikasi Process Activity Mapping untuk menentukan value added, non value added dan necessary but non value added.

Tahap 7 : analisa hasil dan mencari akar penyebab hasil dengan metode 5 why.

Tahap 8 : merekomendasikan dan merencanakan perbaikan.

Tahap 9 : membuat kesimpulan dan saran.

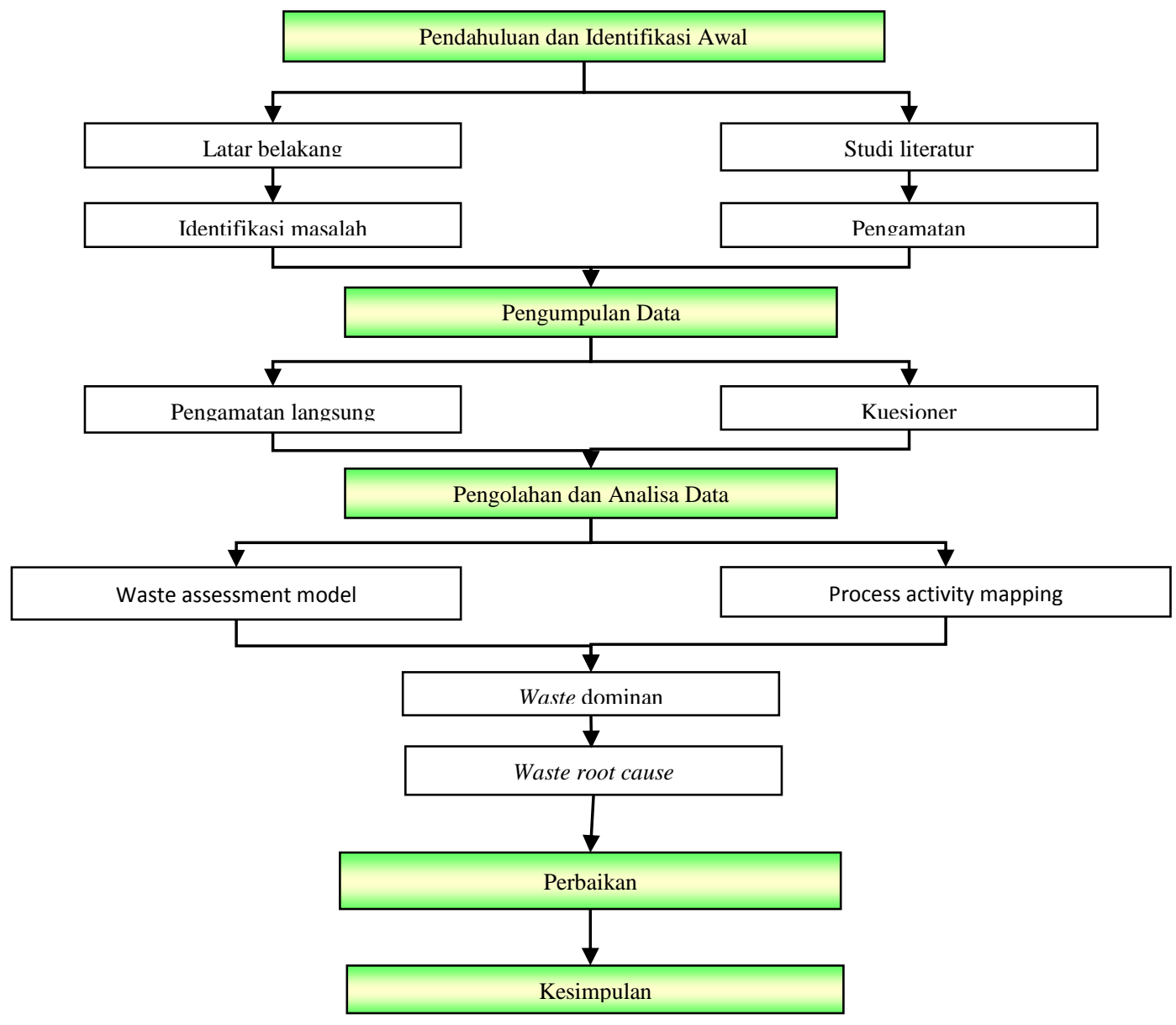

Gambar 1. Alur Penelitian 


\section{HASIL DAN PEMBAHASAN}

\section{Waste assessment model}

Pembuatan daftar kuesioner yang dibagi menjadi 4 kategori: man, material, machine dan method. Jumlah pertanyaan sebanyak 68 pertanyaan dan tiap pertanyaan ditunjuk catatan berupa "from" dan "to" untuk tiap jenis wastenya. Lalu selanjutnya adalah mengelompokkan jumlah pertanyaan berdasarkan "from" dan "to" di atas ke dalam tabel terpisah. Selanjutnya menghitung skor akhir dari waste yang ada berdasarkan data jumlah pertanyaan "from" dan "to", serta menuliskan kembali hasil dari WRM. Semua data di atas digabung menjadi satu tabel. Langkah selanjutnya adalah membagi tiap bobot waste dengan jumlah pertanyaan dalam tiap baris pertanyaan dan dibuatkan tabel terpisah. Nilai skor yang didapat dimasukkan ke masing masing waste dengan cara mengalikannya dengan tiap bobot waste di atas. Nilai skor kemudian dijumlahkan secara vertikal untuk mendapatkan skor $\mathrm{Sj}$ untuk tiap waste, sekaligus juga dihitung untuk frekuensi dari tiap waste yang didapat dengan cara menghitung jumlah nilai selain nilai yang bernilai nol. Indikator awal untuk tiap waste $(\mathrm{Yj})$ dihitung dengan rumus $\mathrm{Yj}=\frac{s j}{s j} \mathrm{x} \frac{f j}{F j} \ldots \ldots$...untuk tiap jenis waste j...(1). Dan nilai final waste faktor (Yj Final) dihitung dengan memasukkan faktor probabilitas pengaruh antar jenis waste $(\mathrm{Pj})$ berdasarkan total presentase "from" dan "to" pada WRM. Yang terakhir mempresentasikan bentuk final waste faktor yang diperoleh sehingga bisa diketahui peringkat level dari masing masing waste. $\mathrm{Yj}$ Final $=\mathrm{Yj} \times \mathrm{Pj}=\frac{s j}{S j} \times \frac{f j}{F j} \times \mathrm{Pj}$; untuk tiap jenis tipe waste $\mathrm{j} . . .(2)$.

Dari hasil metoda di atas didapatkan untuk peringkat waste pertama adalah inventory sebesar $19.23 \%$, diikuti oleh urutan kedua yaitu defect sebesar $18.16 \%$ dan terakhir adalah overproduction sebesar $16.58 \%$.

Tabel 1. Hasil perhitungan waste assessment model

\begin{tabular}{|c|c|c|c|c|c|c|c|}
\hline & $\mathrm{O}$ & $\mathrm{I}$ & $\mathrm{D}$ & $\mathrm{M}$ & $\mathrm{T}$ & $\mathrm{P}$ & $\mathrm{W}$ \\
\hline Skor (Yj) & 0.32 & 0.32 & 0.32 & 0.3 & 0.35 & 0.27 & 0.31 \\
\hline Pj faktor & 228.48 & 264.96 & 250.24 & 231.04 & 166.4 & 109.4 & 147.84 \\
\hline Hasil akhir (Yj final) & 73.11 & 84.79 & 80.08 & 69.31 & 58.24 & 29.55 & 45.83 \\
\hline Hasil akhir (\%) & 16.58 & 19.23 & 18.16 & 15.72 & 13.21 & 6.70 & 10.39 \\
\hline Rangking & $\mathbf{3}$ & $\mathbf{1}$ & $\mathbf{2}$ & $\mathbf{4}$ & $\mathbf{5}$ & $\mathbf{7}$ & $\mathbf{6}$ \\
\hline
\end{tabular}

Hasil karaterisasi SEM yang menunjukan pengaruh pemanasan microwave terhadap perubahan morfologi dan ukuran partikel dari sampel zeolite sehingga menghasilkan perubahan luas permukaan dari partikel zeolite yang ditunjukan oleh hasil BET. Tabel 1. menyajikan hasil karakterisasi BET yang menunjukan bahwa semakin lama permanasan microwave, luas permukaan spesifik dari sampel zeolite $\mathrm{NaX}$ menjadi semakin besar.

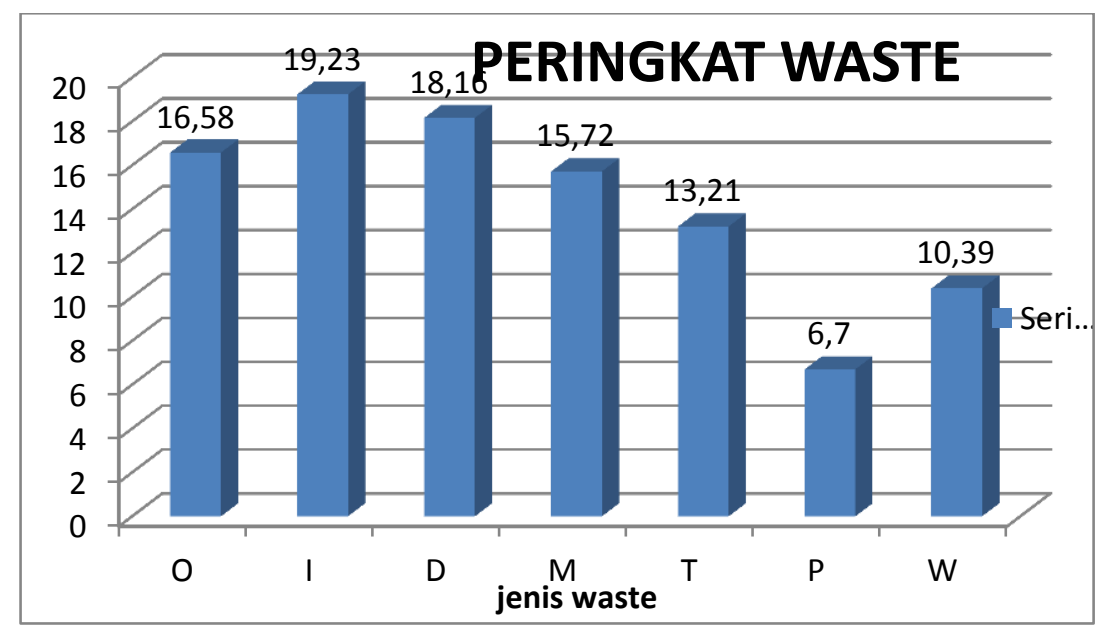

Gambar 2. Grafik peringkat waste 


\section{Process activity mapping}

Data process activity mapping diperoleh dengan melakukan pengukuran aktivitas di dispensing dengan menggunakan stopwatch time study. Terdapat 17 aktivitas utama yang teridentifikasi di dispensing dan pengukuran data waktu diambil sebanyak 30 kali sebagai minimum sampel. Dari hasil pengolahan data process activity mapping maka diperoleh bahwa faktor delay merupakan aktivitas yang memakan waktu terlama sebesar $89.9 \%$. Aktivitas yang bersifat value added sebesar $4.56 \%$, aktifitas yang bersifat necessary but non value added sebesar $6.24 \%$ dan terakhir aktifitas yang bersifat non value added sebesar $89.2 \%$.

\section{Diskusi}

Hasil dari waste relation matrix menjelaskan bahwa ada hubungan pemborosan antara overproduction dengan inventory dan defect. Dimana dengan adanya overproduction dapat mengakibatkan pemborosan yang lain, yaitu inventori dan defect. Hal ini dimungkinkan karena overproduction dapat menyebabkan aliran material menjadi tidak lancar dan cenderung menghambat kualitas dan produktivitas. Memproduksi lebih banyak barang sedangkan barang tersebut belum dibutuhkan dalam waktu dekat akan menyebabkan kelebihan inventori sementara. Pada saat material hasil overproduction tersimpan agak lama dan mengalami berbagai pemindahan maka ada kemungkinan barang tersebut mengalami defect. Pada kasus di dispensing yang dimaksud dengan overproduction adalah membuat preparasi berlebih. Preparasi berlebih ini disebabkan kondisi preparasi yang belum lengkap karena ada raw material yang masih menunggu. Sehingga dengan adanya preparasi yang berlebih tapi belum bisa diproduksi akan mengakibatkan tumpukan inventori yang berlebih. Kemudian dikarenakan tempat dispensing yang terbatas maka tumpukan preparasi preparasi ini sering mengalami pemindahan. Dan pada akhirnya, karena terlalu sering mengalami pemindahan maka ada beberapa material yang mengalami kerusakan.

Hasil waste assessment model menunjukkan bahwa terjadi pemborosan cukup dominan di kategori inventori, disusul defect dan terakhir adalah overproduction. Hal ini masih sama dengan waste relation matrix, sehingga masalahnya adalah sama.

Sementara hasil dari analisa process activity mapping menunjukkan faktor delay yang disebabkan oleh transportasi raw material dari warehouse merupakan faktor yang paling banyak menghabiskan waktu. Penanganan material secara berulang ulang dan pergerakan material yang berlebihan adalah penyebab utama terjadinya kerusakan material. Sehingga hal ini merupakan bukti bahwa transportasi merupakan penyebab utama timbulnya pemborosan lain seperti defect dan menunggu. Delay karena transportasi di dispensing telah menimbulkan efek pemborosan lain seperti pemborosan defect, inventori dan overproduction. Sehingga transportasi ini perlu dipilah pilah untuk dicari yang mana yang termasuk aktivitas non value added. Penyebab timbulnya delay transportasi yang berlebih adalah aliran material dari powder plant ke dispensing dan powder plant ke warehouse.

\section{KESIMPULAN}

1. ada proses di dispensing telah berhasil diidentifikasi pemborosan yang saling berhubungan yaitu inventory, defect dan over production.

2. Pemborosan yang terjadi dapat dikurangi dengan cara:

a. Inventory; suplai dari gudang harus sesuai dengan apa yang dibutuhkan oleh dispensing sehingga seluruh tugas dispensing dapat dituntaskan pekerjaannya sesuai dengan apa yang diminta oleh bagian produksi.

b. Defect; pada saat inventory tidak berlebih maka transportasi yang berlebihan dapat dikurangi sehingga dapat meminimalkan barang yang rusak.

c. Over production; pada saat semua inventory sesuai dengan "apa yang dipesan" maka dispensing hanya akan mengerjakan "apa yang dipesan" sehingga tidak ada job order yang tertunda.

3. Usulan yang diajukan sehubungan dengan temuan pemborosan yang telah ditemukan adalah:

a. Re-lokasi dispensing ke tempat departemen gudang sehingga suplai material lebih dekat, pengelolaan inventory lebih baik dan dapat menghemat biaya transportasi.

b. Re-lay out proses di dispensing dengan memperbaiki area penerimaan material, replenishment material dan proses penimbangan.

c. Menurunkan lead time preparasi dengan cara pengelolaan inventory yang lebih baik.

JIM, Vol. 3, No. 1, Januari 2018, pp.45-50 


\section{DAFTAR PUSTAKA}

Abdul Talib Bon, A. g. (2011). Just in time approach in inventory management. $2^{\text {nd }}$ International Conference On Business and Economic Research Johor:2 ${ }^{\text {nd }}$ ICBER 2011.

Gergova, I. (2012), Warehouse Improvement with Lean 5S - A case study of Ulstein Verft AS. Molde.

Girish C. Pude, P.G. (2012). Application of process activity mapping for waste reduction: a case study in foundry industry. International journal of modern engineering research (IJMER), $3482-3466$.

Rawabdeh, I. A. (2005). A model for the assessment of waste in job shop environment. International journal of operation \& production management, 25

Rich, P. Hines (1997). The seven value stream mapping tools. International journal of operation \& production management, p. $46-64$.

Sobanski, E. (2009). Assessing lean warehousing development and validation of a lean assessment tool. Stillwater: The Oklahoma state university.

V. Ramesh, K. S. (2008). Implementation of a lean model for carrying out value stream mapping in a manufacturing industry. Journal of industrial and system engineering, p. $180-196$. 
